\title{
Clinical Manifestations of $\alpha$-Thalassemia
}

\author{
Elliott P. Vichinsky \\ Department of Hematology/Oncology, Children's Hospital \& Research Center Oakland, Oakland, \\ California 94609 \\ Correspondence: evichinsky@mail.cho.org
}

$\alpha$-Thalassemia mutations affect up to $5 \%$ of the world's population. The clinical spectrum ranges from an asymptomatic condition to a fatal in utero disease. Hemoglobin $\mathrm{H}$ disease results from mutations of three $\alpha$-globin genes. Deletional forms result in a relatively mild anemia, whereas nondeletional mutations result in a moderate to severe disease characterized by ineffective erythropoiesis, recurrent transfusions, and growth delay. Hemosiderosis develops secondary to increased iron absorption, as well as transfusion burden. Hemoglobin Bart's hydrops fetalis is usually a fatal in utero disease caused by the absence of $\alpha$ genes. Population screening to identify at-risk couples is essential. Affected pregnancies result in severe fetal and maternal complications. Doppler ultrasonography with intrauterine transfusion therapy may improve the fetal prognosis but creates ethical challenges for the family and health providers.

$\mathbf{Q}$-Thalassemia syndrome refers to a group of hereditary anemias caused by absent or decreased production of the $\alpha$-chains of hemoglobin. Up to $5 \%$ of the world's population are carriers for these common gene mutations (Weatherall and Clegg 2001; Weatherall 2008). There is marked phenotypic heterogeneity in $\alpha$ thalassemia resulting from the genotypic diversity. At one end of the spectrum is a completely asymptomatic phenotype resulting from one of the four $\alpha$ genes being dysfunctional. At the other end is a fatal in utero disease called hemoglobin Bart's hydrops fetalis, which results from absence of the four $\alpha$ genes.

The phenotype of the $\alpha$-thalassemias is directly related to the number of $\alpha$-globin genes affected. They are divided into the $\alpha^{+}$-thalassemias, in which one of the linked pair of $\alpha$ genes is deleted $(-\alpha / \alpha \alpha)$; and the $\alpha^{0}$-thalassemias, in which both are deleted $(-/ \alpha \alpha)$. The heterozygous state for $\alpha^{+}$-thalassemia is clinically silent, while the heterozygous state for $\alpha^{0}$-thalassemia produces the $\alpha$-thalassemia trait, a condition that is hematologically similar to the $\beta$-thalassemia trait. The homozygous state for $\alpha^{+}$-thalassemia results in a similar phenotype. The inheritance of both $\alpha^{+}$-thalassemia and $\alpha^{0}$-thalassemia $(-\alpha /-)$ results in hemoglobin $\mathrm{H}$ disease. There are also nondeletional forms of $\alpha$-thalassemia $\left(-\alpha^{\mathrm{ND}} / \alpha \alpha\right)$ caused by various structural abnormalities of an $\alpha$-globin gene. When these are inherited together with $\alpha^{0}$-thalassemia $\left(-\alpha^{\mathrm{ND}} /-\right)$, a more severe form of hemoglobin $\mathrm{H}$ disease occurs. Hemoglobin $\mathrm{H}$ is a tetramer of $\beta$-chains $\left(\beta_{4}\right)$, which is unstable and has an extremely high oxygen affinity and is thus unable to effectively deliver oxygen. It is also relatively unstable and causes ineffective

Editors: David Weatherall, Alan N. Schechter, and David G. Nathan

Additional Perspectives on Hemoglobin and Its Diseases available at www.perspectivesinmedicine.org

Copyright (C) 2013 Cold Spring Harbor Laboratory Press; all rights reserved; doi: 10.1101/cshperspect.a011742

Cite this article as Cold Spring Harb Perspect Med 2013;3:a011742 
E.P. Vichinsky

erythropoiesis and a hemolytic anemia. Hemoglobin Bart's, named after the London hospital in which it was discovered, is the fetal counterpart of hemoglobin $\mathrm{H}$ and consists of a tetramer of $\gamma$-chains of fetal hemoglobin $\left(\gamma_{4}\right)$. It too has a very high oxygen affinity, although it is less unstable than hemoglobin $\mathrm{H}$.

\section{EPIDEMIOLOGY}

Worldwide, $\alpha$-thalassemia mutations occur in almost all populations (Williams and Weatherall 2012). They are very common in people of Asian descent; in several regions of China and Southeast Asia, up to $40 \%$ of the population are carriers (Lau et al. 1997; Li et al. 2006; Michlitsch et al. 2009; Vichinsky 2009, 2012; Lal et al. 2011). The Mediterranean and Middle Eastern regions also have a high frequency (Weatherall and Clegg 2001). Immigration patterns have dramatically changed the geographic distribution of $\alpha$-thalassemia (Michlitsch et al. 2009). Once rare in North America, it is becoming a major public health problem. There has been a $2000 \%$ increase in Asian and other at-risk populations immigrating to the United States in the last three decades (Hoppe 2009). This has resulted in California establishing universal newborn screening for $\alpha$-thalassemia, and consideration of a national $\alpha$-thalassemia newborn screening policy (Benz 2011). In the United States, recent studies indicate that in addition to these known at-risk ethnic groups, people of Hispanic and African descent are also at risk (Lam and Tang 2002). In the California Newborn Screening Program, newborns classified as mixed-race are a rapidly growing group born with $\alpha$-thalassemia syndromes (Lam and Tang 2002; Michlitsch et al. 2009). The marked ethnic diversity in California indicates that universal rather than targeted screening is necessary. $\alpha$-Thalassemia syndromes have become the most common nonsickle hemoglobinopathy in California (Table 1). $\alpha$-Thalassemia syndromes are increasingly being diagnosed outside of California. Because most states do not screen for these disorders, the diagnosis is not made until clinical complications occur.
Table 1. California Newborn Screening Program, January 1998-June 2006

\begin{tabular}{lcc}
\hline Diagnosis & $\begin{array}{c}\text { Newborns } \\
\text { identified }\end{array}$ & $\begin{array}{c}\text { Incidence } \\
\text { (per 100,000 } \\
\text { screened) }\end{array}$ \\
\hline $\boldsymbol{\alpha}$-Thalassemia & 502 & 11.1 \\
$\quad$ syndromes & & \\
Hb H disease & 406 & 9.0 \\
Hb H with Hb E trait & 35 & 0.8 \\
Hb H with Hb EE & 16 & 0.4 \\
Hb H Constant Spring & 25 & 0.6 \\
Hb H with other & 8 & 0.2 \\
$\quad$ variants & & \\
Hb H with SS & 7 & 0.2 \\
Hb Bart's hydrops & 5 & 0.1 \\
fetalis & \\
a-Thalassemia & & \\
$\quad$ syndromes & 79 & 1.8 \\
$\beta^{0}$-Thalassemia & 19 & 0.4 \\
Hb E/ $\beta^{0}$-thalassemia & 31 & 0.7 \\
Hb C/ $\beta^{0}$-thalassemia & 7 & 0.2 \\
Hb D $/ \beta^{0}$-thalassemia & 5 & 0.1 \\
Hb C/ $\beta^{+}$-thalassemia & 14 & 0.3 \\
Hb E $/ \beta^{+}$-thalassemia & 3 & 0.1 \\
Other mutations & 862 & 19.1 \\
Hb EE & 514 & 11.4 \\
Hb CC & 41 & 0.9 \\
Hb C-HPFH & 3 & 0.1 \\
Heterozygous variants & 304 & 6.7 \\
\hline
\end{tabular}

Data from Michlitsch et al. 2009.

$\mathrm{Hb}$, hemoglobin; HPFH, hereditary persistence of fetal hemoglobin.

aAll five cases of $\mathrm{Hb}$ Bart's hydrops fetalis were homozygous for the Southeast Asian (SEA) deletion mutation.

The numerous molecular forms of $\alpha$-thalassemia are reviewed by Higgs (2013). There are two common deletional forms of $\alpha^{+}$-thalassemia, described by the size of the particular deletion, $-\alpha^{3.7}$ and $-\alpha^{4.2}$. There are many different forms of $\alpha^{0}$-thalassemia that result from different-sized deletions of the $\alpha$-globin genes. Most of them are named by the place of origin of their discovery. The most common form is the Southeast Asian deletion ( $-{ }^{\text {SEA }}$ ) (Chui and Waye 1998; Hoppe 2009). This deletion involves both $\alpha$ genes but not the embryonic globin genes (Chui and Waye 1998). Other $\alpha$-thalassemias such as the Thai form $\left(-{ }^{\mathrm{THAI}}\right)$ also remove the 
embryonic globin genes. There are also many different nondeletional forms of $\alpha$-thalassemia, many of which are also named after their place of origin. The clinical phenotypes of hemoglobin $\mathrm{H}$ disease that result from the interaction of nondeletional mutations $\left(-/ \alpha^{\mathrm{ND}} \alpha\right)$ are more severe and less common than the deletional forms $(-\alpha /-)$ (Lau et al. 1997; Lorey et al. 2001a; $\mathrm{Ne}$ et al. 2008; Michlitsch et al. 2009; Singer et al. 2009; Kidd et al. 2010; Lal et al. 2011; Vichinsky 2012). The most common interaction of this type is with the $\alpha$-globin chain-termination mutant, Hb Constant Spring $\left(-/ \alpha^{\mathrm{CS}} \alpha\right)$, which accounts for approximately $27 \%$ of hemoglobin $\mathrm{H}$ diseases in California (Table 2) and which occurs frequently in many countries in Southeast Asia.

\section{THE MILDER FORMS OF $\alpha$-THALASSEMIA}

The milder forms of $\alpha$-thalassemia are reviewed in detail by Weatherall and Clegg (2001). The heterozygous states for deletional $(-\alpha / \alpha \alpha)$ and nondeletional $\left(\alpha^{\mathrm{ND}} \alpha / \alpha \alpha\right) \alpha$-thalassemia are associated with extremely mild reductions in the red cell indices that overlap with normal values. At birth some, but not all, cases have slightly elevated levels of hemoglobin Bart's, which disappears over the first year of life and is not replaced by hemoglobin H. The homozygous state for these conditions is characterized by a mild hypochromic microcytic anemia with

Table 2. Hemoglobin H disease genotypes identified by the California Newborn Screening Program, January 2006-December 2008

\begin{tabular}{lcc}
\hline Genotype & $\begin{array}{c}\text { Newborns } \\
\text { identified }\end{array}$ & $\begin{array}{c}\text { Estimated birth } \\
\text { prevalence (per } \\
100,000)\end{array}$ \\
\hline$\alpha^{3.7} /$ SEA & 85 & 5 \\
$\alpha^{3.7} /$ FIL & 25 & 1.5 \\
$\alpha^{4.2} /$ SEA & 5 & 0.3 \\
$\alpha^{3.7} /$ THAI & 1 & 0.05 \\
$\alpha^{4.2} /$ FIL & 1 & 0.05 \\
$\alpha^{\mathrm{CS}} \alpha /$ SEA & 13 & 0.77 \\
$\alpha^{\text {PolyA } \alpha / \text { SEA }}$ & 1 & 0.05 \\
SEA/SEA & 3 & 0.17 \\
Total & 134 & 8 \\
\hline
\end{tabular}

Data from Hoppe 2009. significantly reduced levels of mean corpuscular volume (MCV) and mean corpuscular hemoglobin $(\mathrm{MCH})$ and elevated levels of hemoglobin Bart's at birth.

Hence these conditions themselves are of no clinical significance and their major importance is the modifying effect that they have on various severe forms of $\beta$-thalassemia and sickle cell anemia. These interactions are summarized by Musallam et al. (2012), Fucharoen and Weatherall (2012), and Lettre (2012). As discussed in a later section, their identification is vital in population screening for couples at risk for the more severe forms of $\alpha$ thalassemia.

\section{HEMOGLOBIN H DISEASE}

\section{Clinical Severity}

Hemoglobin $\mathrm{H}$-Constant Spring and deletional hemoglobin $\mathrm{H}$ disease are two distinct clinical entities (Lal et al. 2011). Patients with hemoglobin $\mathrm{H}$-Constant Spring commonly have complications develop within the first decade of childhood, including significant growth delay, recurrent transfusions, and iron overload (Table 3) (Chui et al. 2003; Fucharoen and Viprakasit 2009; Singer et al. 2009; Benz 2011; Lal et al. 2011; Vichinsky 2012). They are particularly at risk for sudden, severe anemia following acute febrile illness. Often these infections may be mild. Most patients by 10 years of age have received recurrent transfusions. The acute anemic events are usually hemolytic and have associated increases in bilirubin and reticulocyte counts. Hypoplastic acute anemic events secondary to parvovirus and other viral infections account for $20 \%$ of acute anemic episodes. In addition to febrile events, pregnancy often is associated with unexpected decreases in hemoglobin levels.

The anemia of hemoglobin $\mathrm{H}$ disease results from the deficit of $\alpha$-globin expression, which is more severe in the nondeletional form (Table 3). Membrane injury from oxidative damage results in shortened red cell survival (Pootrakul et al. 2000; Fucharoen and Viprakasit 2009). The hemolytic anemia may result in the 
E.P. Vichinsky

Table 3. Clinical and hematologic manifestation of hemoglobin $\mathrm{H}$ disease

\begin{tabular}{lll}
\hline Clinical manifestation & \multicolumn{1}{c}{ Deletional } & \multicolumn{1}{c}{ Nondeletional } \\
\hline Hemoglobin $(\mathrm{g} / \mathrm{dL})$ & 8.5 (range, 6.9-10.7) & 7.2 (range, 3.8-8.7) \\
MCV (fL) & $54.0($ range, $46.0-76.0)$ & 65.2 (range, 48.7-80.7) \\
MCH (pg) & $16.6($ range, 14.3-24.7) & 18.6 (range, 14.8-24.8) \\
Anemia & Microcytic & Normocytic \\
Reticulocytosis & + & ++ \\
Hypochromia & ++ & + \\
Age at first transfusion (yr) & $11 \pm 5.5$ & $1.5 \pm 2.1$ \\
History of blood transfusion (\%) & $3-29$ & $24-80$ \\
Splenomegaly & + & +++ \\
Gallstones & + & ++ \\
Growth retardation & Rare & Common \\
Decreased bone density & Rare & Common \\
\hline
\end{tabular}

Data from Vichinsky 2009.

$\mathrm{MCH}$, mean corpuscular hemoglobin; MCV, mean corpuscular volume.

development of cholelithiasis. There is intramedullary death of erythroblasts resulting in ineffective erythropoiesis. This is supported by the finding of markedly elevated serum transferrin receptor levels in hemoglobin $\mathrm{H}$-Constant Spring. Phosphatidylserine exposure on the red cell surface further increases the morbidity of the disease, including an increased risk of thrombosis (Yuan et al. 1995).

The chronic anemia is more severe in hemoglobin $\mathrm{H}-$ Constant Spring than in deletional hemoglobin $\mathrm{H}$ disease and often results in transfusion therapy in childhood (Fig. 1) (Lal et al. 2011).

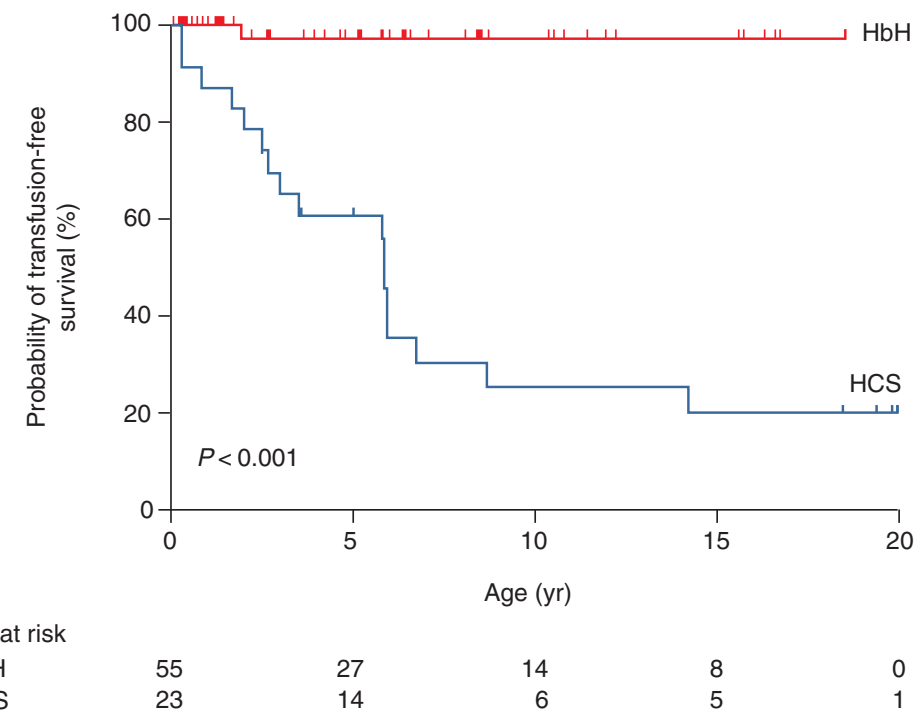

Figure 1. Age at first transfusion for patients with deletional hemoglobin $\mathrm{H}$ disease $(\mathrm{HbH})$ and hemoglobin $\mathrm{H}-$ Constant Spring disease (HCS). Excluded from the analysis in the $\mathrm{HbH}$ group are five patients whose first clinic visit occurred after the age of 20 years and three patients with nondeletional HbH disease. (From Lal et al. 2011; reprinted, with permission, (C) The Massachusetts Medical Society.) 
The mean hemoglobin level in infants with deletional hemoglobin $\mathrm{H}$ disease is $8.5 \mathrm{~g} / \mathrm{dL}$ (range, 6.9-10.7) and increases to $9.4 \mathrm{~g} / \mathrm{dL}$ with age. In infants with hemoglobin $\mathrm{H}-\mathrm{Con}$ stant Spring, the mean hemoglobin level is 7.0 $\mathrm{g} / \mathrm{dL}$ (range, 5.8-9.5) and changes little with age (Chui et al. 2003; Fucharoen and Viprakasit 2009; Lal et al. 2011; Vichinsky 2012). Although hemoglobin $\mathrm{H}$-Constant Spring is more severe, red cell indices are less affected. The red cell MCV is markedly reduced in hemoglobin $\mathrm{H}$ deletion patients (54.0 fL; range, 46.0-76.0). In contrast, the MCV in the hemoglobin $\mathrm{H}-\mathrm{Con}$ stant Spring group is $65.2 \mathrm{fL}$ (range, 48.7-80.7). Hemoglobin E is often coinherited with hemoglobin $\mathrm{H}$ and its effects are variable. It may lower the MCV but decrease the hemolytic anemia (Fucharoen and Weatherall 2012).

Splenomegaly is more common in nondeletional hemoglobin $\mathrm{H}$ disease and may correlate with the clinical severity of the disease (Fig. 2) (Styles et al. 1997; Vichinsky 2010). Splenectomy is helpful in decreasing extravascular hemolysis and increasing the hemoglobin. Patients with hemoglobin $\mathrm{H}$-Constant Spring often have a significant increase in hemoglobin following splenectomy. Transfusion-dependent patients may become transfusion-independent following surgery. However, splenectomy increases the rate of thrombosis (Tso et al. 1982). Chronic anticoagulation therapy may be nec- essary to prevent serious thrombotic complications. Portal vein thrombosis may be a perioperative postsplenectomy complication. Early screening of perioperative patients with abdominal symptoms is warranted. Splenectomy may be necessary in infants, and therefore prophylactic antibiotics are required.

Iron overload is a common, underdiagnosed problem in hemoglobin H disorders (Fucharoen and Viprakasit 2009; Singer et al. 2009; Benz 2011; Lal et al. 2011; Vichinsky 2012). The ferritin increases with age irrespective of the transfusion history and may underestimate body iron stores (Fig. 3) (Lal et al. 2011). Increased dietary iron absorption continues throughout life and results in hemosiderosis-related complications in some adults. Elevated pituitary, pancreatic, and cardiac iron has been observed, particularly in hemoglobin $\mathrm{H}-$ Constant Spring. Older patients are at risk for cardiac and endocrine dysfunction (Chui et al. 2003; Chan et al. 2006; Au et al. 2009; Fucharoen and Viprakasit 2009; Singer et al. 2009). Oral iron chelation has been beneficial in patients with elevated body iron stores (Au et al. 2009).

\section{Laboratory Screening and Diagnosis}

The hemoglobin and red cell indices are helpful in identifying patients. However, they are nonspecific findings. In addition, in hemoglobin

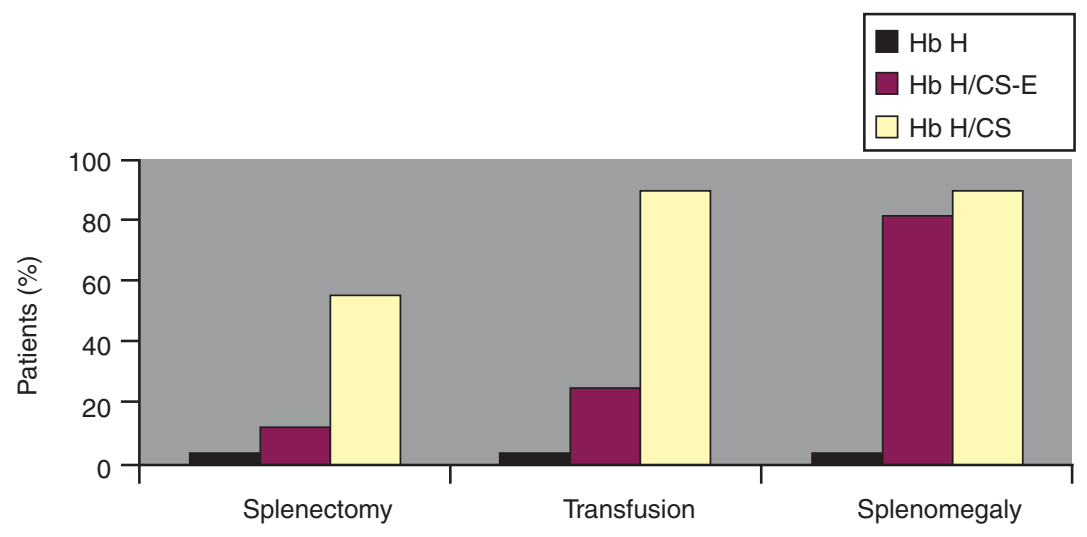

Figure 2. Comparison of the rate of splenectomy, transfusion, and splenomegaly history in three types of hemoglobin $(\mathrm{Hb}) \mathrm{H}$ disease: $\mathrm{Hb} \mathrm{H}$ (three-gene deletion), $\mathrm{Hb} \mathrm{H} / \mathrm{CS}$ ( $\mathrm{Hb} \mathrm{H}$ with Constant Spring), and $\mathrm{Hb}$ $\mathrm{H} / \mathrm{CS}-\mathrm{E}(\mathrm{Hb} \mathrm{H} / \mathrm{CS}+$ heterozygote for Hb E). (From Styles et al. 1997; reprinted, with permission.) 
E.P. Vichinsky

A Serum ferritin in $\mathrm{HbH}$

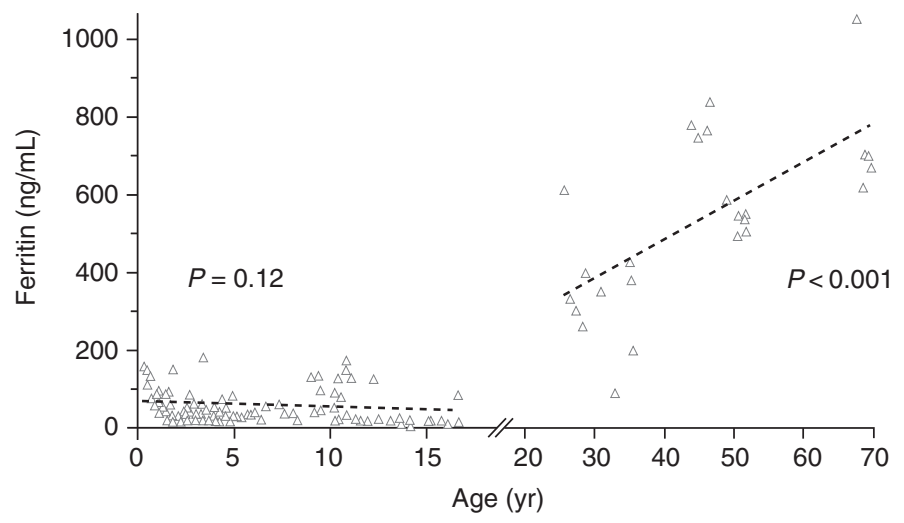

B Serum ferritin in HCS
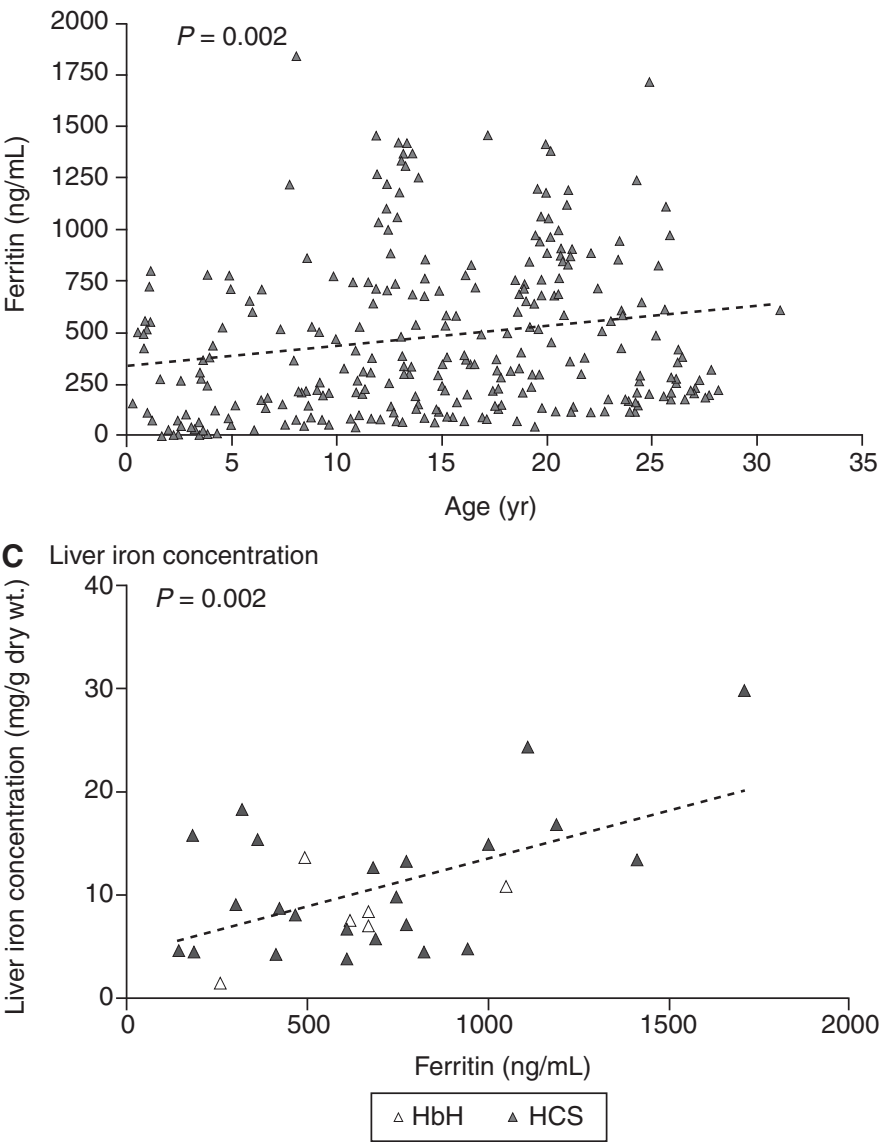

Figure 3. Serum ferritin levels in patients with deletional hemoglobin $\mathrm{H}$ disease $(\mathrm{HbH})$ and hemoglobin $\mathrm{H}-$ Constant Spring disease (HCS) and correlation with liver iron concentration. The trend for ferritin levels according to age on the basis of linear regression (dashed line) increases after the age of 18 years in patients with $\mathrm{HbH}(A)$, and increases from birth to the age of 30 years in those with $\mathrm{HCS}(B)$. A significant correlation between the serum ferritin level and liver iron concentration is shown in patients with $\mathrm{HbH}$ and HCS $(C)$, with the dashed line indicating the linear regression of liver iron concentration as compared with ferritin. (From Lal et al. 2011; reprinted, with permission, (C) The Massachusetts Medical Society.) 
$\mathrm{H}$-Constant Spring, microcytosis may not be observed. Red cell inclusion bodies may be observed after supravital stain analysis with brilliant cresyl blue (Fig. 4) (Fucharoen and Viprakasit 2009). These inclusions are markedly increased after splenectomy. Hemoglobin electrophoresis may demonstrate a hemoglobin $\mathrm{H}$ band. However, hemoglobin $\mathrm{H}$ is unstable and is often missed, particularly if the blood sample has been frozen or if organic solvents are used to prepare the hemoglobin for analysis. Hemoglobin $\mathrm{A}_{2}$ levels are lower in $\alpha$-thalassemia disorders. Automated high-performance liquid chromatography (HPLC) is an excellent screening method for high-risk populations and in newborn screening programs (Lorey et al. 2001a; Hoppe 2009; Michlitsch et al. 2009; Kidd et al. 2010). In the neonatal period, hemoglobin Bart's is commonly seen on HPLC or hemoglobin electrophoresis. Hemoglobin Bart's is an aggregate of $\gamma$-chains that reflects the high fetal hemoglobin observed in neonates. It rapidly disappears following birth. The quantitation of hemoglobin Bart's correlates with the severity of the $\alpha$-thalassemia disorder. Bart's hemoglobin levels of $>25 \%$ indicate hemoglobin $\mathrm{H}$ disease. Definitive diagnosis requires molecular genetic testing. Multiplex genotyping assays using gap polymerase chain reaction can rapidly diagnose most deletional and nondeletional mutations (Kidd et al. 2010). Confirmatory pa-

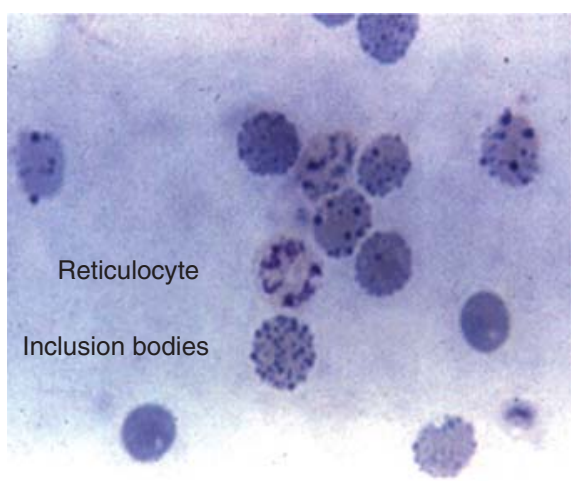

Figure 4. Red cell inclusion body induced after incubation of red cell with brilliant cresyl blue. (From Fucharoen and Viprakasit 2009; reprinted, with permission, (C) American Society of Hematology.) rental studies should always be performed in newborns and children identified with hemoglobin $\mathrm{H}$. Patients with $\alpha$-thalassemia disorders often coinherit other mutations including hemoglobin E, $\beta$-thalassemia, and hemoglobin S (Li et al. 2006; Liao et al. 2007; Hoppe 2009). In addition, the same population may be at risk for glucose phosphate dehydrogenase deficiency.

\section{Management}

Hemoglobin $\mathrm{H}$ patients require ongoing monitoring of growth, quality of life, and laboratory markers of organ dysfunction. Dietary supplement with folate and multivitamins without iron is indicated (Lal et al. 2011). Patients may develop calcium and vitamin D deficiency. Monitoring bone density in older patients is indicated. Iron supplementation should be avoided. The decision to chronically transfuse patients is difficult. Brief periods of transfusion during childhood development and pregnancy may be indicated (Fucharoen and Viprakasit 2009; Singer et al. 2009; Lal et al. 2011). Oral iron chelation therapy may be beneficial in patients with hemosiderosis. The dosage indicated in nontransfusion-dependent patients is lower than in transfused patients and requires ongoing reassessment. Splenectomy is a serious undertaking, and its risks and benefits should be reviewed with each case. Aspirin or other anticoagulant therapy should always be considered following splenectomy. Chronic fatigue may develop in older patients, and quality-of-life assessments are helpful in management decisions. Family screening and genetic counseling are important. Preventative education concerning the risk of severe anemia with acute infections is important.

\section{HEMOGLOBIN BART'S HYDROPS FETALIS}

Hemoglobin Bart's hydrops fetalis is a devastating and fatal disease. It is an important public health problem in many regions of the world. Although advances in intrauterine therapy have resulted in long-term survival, these cases are rare. Prevention through family screening and education is the most effective treatment. 
E.P. Vichinsky

Homozygosity for - ${ }^{\text {SEA }}$ is a common cause of hydrops fetalis. Because the mutation does not affect functional embryonic hemoglobin production, pregnancy continues to late gestation, allowing for the clinical manifestation of hydrops fetalis. Larger mutations that prevent embryonic hemoglobin production are often undiagnosed terminations. The severity of the disease is clearly influenced by the type of $\alpha$-globin mutations. Nondeletional mutations and hyperunstable mutations increase the severity (Chan et al. 1997; Lorey et al. 2001b; Suwanrath-Kengpol et al. 2005; Siriratmanawong et al. 2007; Fucharoen and Viprakasit 2009; Hoppe 2009; Vichinsky 2009). When severe mutations are involved, hydrops fetalis can result from only three genes being affected.

Early in gestation, functional embryonic hemoglobin is responsible for oxygen delivery. After two months of gestation, a switch to hemoglobin F production occurs. Normal fetal hemoglobin cannot be produced without $\alpha$ chains. Hemoglobin Bart's, which cannot deliver oxygen to tissues, becomes the major hemoglobin. Therefore, the severity of the disease is underestimated by the intrauterine hemoglobin level. The midtrimester intrauterine hemoglobin analysis demonstrates an average hemoglobin of $6.4 \mathrm{~g} / \mathrm{dL}$ in hemoglobin Bart's hydrops fetalis (Table 4) (Srisupundit et al. 2008). Here is severe, ineffective erythropoiesis with marked extramedullary hematopoiesis. This leads to massive organomegaly, heart failure, gross body edema, and eventual intrauterine demise. Fetal hypoxia also causes developmental anomalies in approximately $20 \%$ of cases (Liang et al. 1985; Singer et al. 2000; Adam et al. 2005; Vichinsky 2009). Most of these anomalies are mild, involving the genitourinary and skeletal systems. However, severe malformations do occur. These are very high-risk pregnancies, and those not receiving close monitoring have a high mortality rate. The majority of pregnancies are complicated by hypertension, preeclampsia, and several other serious complications (Liang et al. 1985; Suwanrath-Kengpol et al. 2005; Vichinsky 2009; Yang and Li 2009).

\section{Prevention and Prenatal Management}

$\alpha$-Thalassemia major is a public health problem requiring community education and screening of at-risk populations. Microcytosis, hemoglobin levels, and electrophoresis are useful initial screening tests. Once an index case is identified, his or her partner should be tested to identify atrisk couples. All identified at-risk couples require molecular diagnosis to determine family planning decisions. In high-risk couples, molecular diagnosis on fetal tissue is obtained early in pregnancy by chorionic villus sampling. Later in pregnancy, hydrops fetalis and anemia can be detected by Doppler ultrasonography of the middle cerebral arteries in $90 \%$ of cases (Mari et al. 2000; Lam and Tang 2002; Leung et al. 2002; Zimmerman et al. 2002; Hofstaetter et al. 2006; Oepkes et al. 2006; Moise 2008; Vichinsky 2009). Middle cerebral artery measurements can be monitored after 16 weeks of gestation and reliably determine intrauterine anemia. Fetal

Table 4. Hematology of red blood cell indices in midpregnancy fetuses

\begin{tabular}{lcccr}
\hline & $\begin{array}{c}\text { Normal } \\
(n=22)\end{array}$ & $\begin{array}{c}\alpha 1 \text { trait }^{\text {a }} \\
\text { Parameter }(m=40)\end{array}$ & $\begin{array}{c}\text { Hb Bart's hydrops } \\
(n=26)\end{array}$ & \multicolumn{1}{c}{$P$} \\
\hline Gestational age $(\mathrm{wk})$ & $18.9+9.5$ & $18.6+7.9$ & $18.8+8.8$ & .422 \\
Hb level $(\mathrm{g} / \mathrm{dL})$ & $11.34 \pm 0.83$ & $10.42 \pm 0.91$ & $6.4 \pm 1.64$ & $<.001$ \\
MCV $(\mathrm{fL})$ & $123.40 \pm 7.76$ & $105.95 \pm 7.35$ & $96.26 \pm 8.19$ & $<.001$ \\
MCH (pg) & $41.39 \pm 3.35$ & $33.71 \pm 2.74$ & $26.23 \pm 2.6$ & $<.001$ \\
MCHC (g/dL) & $33.44 \pm 1.3$ & $31.81 \pm 1.09$ & $27.29 \pm 1.78$ & .001 \\
\hline
\end{tabular}

ANOVA test before post hoc multiple comparisons (fetuses, $n=86$ ). (Data from Srisupundit et al. 2008.)

$\mathrm{Hb}$, hemoglobin; $\mathrm{MCV}$, mean corpuscular volume; $\mathrm{MCH}$, mean corpuscular hemoglobin; $\mathrm{MCHC}$, mean corpuscular hemoglobin concentration.

${ }^{\mathrm{a}} \alpha 1$ trait is the heterozygous state for $\alpha^{0}$-thalassemia $(-/ \alpha \alpha)$. 
survival without intrauterine transfusion is increasinglybeing identified. These newborns have severe neonatal complications and are at high risk for major neurocognitive dysfunction (Singer et al. 2000; Lucke et al. 2005; Suwanrath-Kengpol et al. 2005; Lee et al. 2007; Vichinsky 2009, 2012). Intrauterine transfusion appears to minimize these complications (Carr et al. 1995; Vichinsky 2009; Weisz et al. 2009; Yi et al. 2009). However, these newborns will require lifetime transfusion therapy or stem cell transplantation (Zhou et al. 2001; Yi et al. 2009; Vichinsky et al. 2010).

\section{SUMMARY}

$\alpha$-Thalassemia syndromes are common and have a wide range of clinical phenotypes. Hemoglobin $\mathrm{H}$ disease morbidity is often underappreciated. These patients require early diagnosis and ongoing monitoring. Hemoglobin Bart's hydrops is a tragic, usually fatal complication that can be prevented by adequate screening and counseling. Improved outcome with intrauterine transfusions creates ethical issues for the family and health care providers.

\section{REFERENCES}

* Reference is also in this collection.

Adam MP, Chueh J, El-Sayed YY, Stenzel A, Vogel H, Weaver DD, Hoyme HE. 2005. Vascular-type disruptive defects in fetuses with homozygous $\alpha$-thalassemia: Report of two cases and review of the literature. Prenat Diagn 25: 1088-1096.

Au WY, Lam WW, Chu WW, Tam S, Wong WK, Lau J, Yeung YM, Liu HS, Liang R. 2009. Organ-specific hemosiderosis and functional correlation in Chinese patients with thalassemia intermedia and hemoglobin $\mathrm{H}$ disease. Ann Hematol 88: 947-950.

Benz EJ Jr. 2011. Newborn screening for $\alpha$-thalassemiakeeping up with globalization. NEnglJMed 364: 770-771.

Carr S, Rubin L, Dixon D, Star J, Dailey J. 1995. Intrauterine therapy for homozygous $\alpha$-thalassemia. Obstet Gynecol 85: 876-879.

Chan V, Chan VW, Tang M, Lau K, Todd D, Chan TK. 1997. Molecular defects in $\mathrm{Hb} \mathrm{H}$ hydrops fetalis. Br J Haematol 96: $224-228$.

Chan JC, Chim CS, Ooi CG, Cheung B, Liang R, Chan TK, Chan V. 2006. Use of the oral chelator deferiprone in the treatment of iron overload in patients with $\mathrm{Hb} \mathrm{H}$ disease. Br J Haematol 133: 198-205.
Chui DH, Waye JS. 1998. Hydrops fetalis caused by $\alpha$-thalassemia: An emerging health care problem. Blood 91: 2213-2222.

Chui DH, Fucharoen S, Chan V. 2003. Hemoglobin H disease: Not necessarily a benign disorder. Blood 101: 791-800.

Fucharoen S, Viprakasit V. 2009. Hb H disease: Clinical course and disease modifiers. Hematology Am Soc Hematol Educ Program 26-34.

* Fucharoen S, Weatherall DJ. 2012. The hemoglobin E thalassemias. Cold Spring Harb Perspect Med 2: a011734.

* Higgs DR. 2013. The molecular basis of $\alpha$-thalassemia. Cold Spring Harb Perspect Med 3: a011718.

Hofstaetter C, Hansmann M, Eik-Nes SH, Huhta JC, Luther SL. 2006. A cardiovascular profile score in the surveillance of fetal hydrops. J Matern Fetal Neonatal Med 19: 407-413.

Hoppe CC. 2009. Newborn screening for non-sickling hemoglobinopathies. Hematology Am Soc Hematol Educ Program 19-25.

Kidd JL, Azimi M, Lubin B, Vichinsky E, Hoppe C. 2010 Application of an expanded multiplex genotyping assay for the simultaneous detection of Hemoglobin Constant Spring and common deletional $\alpha$-thalassemia mutations. Int J Lab Hematol 32: 373-380.

Lal A, Goldrich ML, Haines DA, Azimi M, Singer ST, Vichinsky EP. 2011. Heterogeneity of hemoglobin H disease in childhood. $N$ Engl J Med 364: 710-718.

Lam YH, Tang MH. 2002. Middle cerebral artery Doppler study in fetuses with homozygous $\alpha$-thalassaemia-1 at 12-13 weeks of gestation. Prenat Diagn 22: 56-58.

Lau YL, Chan LC, Chan YY, Ha SY, Yeung CY, Waye JS, Chui DH. 1997. Prevalence and genotypes of $\alpha$ - and $\beta$ thalassemia carriers in Hong-implications for population screening. N Engl J Med 336: 1298-1301.

Lee SY, Chow CB, Li CK, Chiu MC. 2007. Outcome of intensive care of homozygous $\alpha$-thalassaemia without prior intra-uterine therapy. J Paediatr Child Health 43: 546-550.

* Lettre G. 2012. The search for genetic modifiers of disease severity in the $\beta$-hemoglobinopathies. Cold Spring Harb Perspect Med 2: a015032.

Leung WC, Oepkes D, Seaward G, Ryan G. 2002. Serial sonographic findings of four fetuses with homozygous $\alpha$-thalassemia-1 from 21 weeks onwards. Ultrasound $\mathrm{Ob}$ stet Gynecol 19: 56-59.

Li D, Liao C, Li J, Xie X, Huang Y, Zhong H. 2006. Detection of $\alpha$-thalassemia in $\beta$-thalassemia carriers and prevention of Hb Bart's hydrops fetalis through prenatal screening. Haematologica 91: 649-651.

Liang ST, Wong VC, So WW, Ma HK, Chan V, Todd D. 1985. Homozygous $\alpha$-thalassaemia: Clinical presentation, diagnosis and management. A review of 46 cases. Br J Obstet Gynaecol 92: 680-684.

Liao C, Li Q, Wei J, Feng Q, Li J, Huang Y, Li D. 2007. Prenatal control of Hb Bart's disease in southern China. Hemoglobin 31: 471-475.

Lorey F, Cunningham G, Vichinsky EP, Lubin BH, Witkowska HE, Matsunaga A, Azimi M, Sherwin J, Eastman J, Farina F, et al. 2001a. Universal newborn screening for $\mathrm{Hb}$ $\mathrm{H}$ disease in California. Genet Test 5: 93-100. 
E.P. Vichinsky

Lorey F, Charoenkwan P, Witkowska HE, Lafferty J, Patterson M, Eng B, Waye JS, Finklestein JZ, Chui DH. 2001b. Hb H hydrops foetalis syndrome: A case report and review of literature. Br J Haematol 115: 72-78.

Lucke T, Pfister S, Durken M. 2005. Neurodevelopmental outcome and haematological course of a long-time survivor with homozygous $\alpha$-thalassaemia: Case report and review of the literature. Acta Paediatr 94: 1330-1333.

Mari G, Deter RL, Carpenter RL, Rahman F, Zimmerman R, Moise KJ Jr, Dorman KF, Ludomirsky A, Gonzalez R, Gomez R, et al. 2000. Noninvasive diagnosis by Doppler ultrasonography of fetal anemia due to maternal red-cell alloimmunization. Collaborative Group for Doppler Assessment of the Blood Velocity in Anemic Fetuses. N Engl $J$ Med 342: 9-14.

Michlitsch J, Azimi M, Hoppe C, Walters MC, Lubin B, Lorey F, Vichinsky E. 2009. Newborn screening for hemoglobinopathies in California. Pediatr Blood Cancer 52: 486-490.

Moise KJ Jr. 2008. The usefulness of middle cerebral artery Doppler assessment in the treatment of the fetus at risk for anemia. Am J Obstet Gynecol 198: e161-e164.

* Musallam KM, Taher AT, Rachmilewitz EA. 2012. $\beta$-Thalassemia intermedia: A clinical perspective. Cold Spring Harb Perspect Med 2: a013482.

Ne W, Harano K, Harano T, Kyaw-S, Aye-Aye M, Khin T-A, Okada S. 2008. Hb Constant Spring [ $\alpha 142$, Term $\rightarrow$ Gln (TAA > CAA in $\alpha 2$ )] in the $\alpha$-thalassemia of anemic patients in Myanmar. Hemoglobin 32: 454-461.

Oepkes D, Seaward PG, Vandenbussche FP, Windrim R, Kingdom J, Beyene J, Kanhai HH, Ohlsson A, Ryan G, DIAMOND Study Group. 2006. Doppler ultrasonography versus amniocentesis to predict fetal anemia. $N$ Engl J Med 355: 156-164.

Pootrakul P, Sirankapracha P, Hemsorach S, Moungsub W, Jumbunlue R, Plangitjagum A, Wasl P, Ma L, Schrier SL. 2000. A correlation of erythrokinetics, ineffective erythropoiesis, and erythroid precursor apoptosis in Thai patients with thalassemia. Blood 96: 2606-2612.

Singer ST, Styles L, Bojanowski J, Quirolo K, Foote D, Vichinsky EP. 2000. Changing outcome of homozygous $\alpha$-thalassemia: Cautious optimism. J Pediatr Hematol Oncol 22: 539-542.

Singer ST, Kim HY, Olivieri NF, Kwiatkowski JL, Coates TD, Carson S, Neufeld E, Cunningham MJ, Giardina PJ, Mueller BU, et al. 2009. Hemoglobin H-constant spring in North America: An $\alpha$ thalassemia with frequent complications. Am J Hematol 84: 759-761.

Siriratmanawong N, Pinmuang-Ngam C, Fucharoen G, Fucharoen S. 2007. Prenatal diagnosis of Hb Bart's hydrops fetalis caused by a genetic compound heterozygosity for two different $\alpha^{0}$-thalassemia determinants. Fetal Diagn Ther 22: 264-268.

Srisupundit K, Piyamongkol W, Tongsong T. 2008. Comparison of red blood cell hematology among normal, $\alpha$-thal- assemia-1 trait, and hemoglobin Bart's fetuses at midpregnancy. Am J Hematol 83: 908-910.

Styles L, Foote D, Kleman K, Vichinsky E. 1997. Hemoglobin H-Constant Spring disease: An under recognized, severe form of $\alpha$ thalassemia. Int J Pediatr Hematol Oncol 6: $69-74$.

Suwanrath-Kengpol C, Kor-anantakul O, Suntharasaj T, Leetanaporn R. 2005. Etiology and outcome of non-immune hydrops fetalis in southern Thailand. Gynecol Obstet Invest 59: 134-137.

Tso SC, Chan TK, Todd D. 1982. Venous thrombosis in haemoglobin $\mathrm{H}$ disease after splenectomy. Aust $\mathrm{NZ} \mathrm{J}$ Med 12: 635-638.

Vichinsky EP. 2009. $\alpha$ Thalassemia major-new mutations, intrauterine management, and outcomes. Hematology Am Soc Hematol Educ Program 35-41.

Vichinsky E. 2010. Complexity of $\alpha$ thalassemia: Growing health problem with new approaches to screening, diagnosis, and therapy. Ann NY Acad Sci 1202: 180-187.

Vichinsky E. 2012. Advances in the treatment of $\alpha$-thalassemia. Blood Rev 26: S31-S34.

Vichinsky E, Chu J, Walters M, et al. 2010. Successful hematopoietic cell transplantation for $\alpha$ thalassemia major Pediatr Blood Cancer 54: 840.

Weatherall DJ. 2008. Hemoglobinopathies worldwide: Present and future. Curr Mol Med 8: 592-599.

Weatherall DJ, Clegg JB, ed. 2001. The thalassaemia syndromes, 4 th ed. Blackwell Science, Malden, MA.

Weisz B, Rosenbaum O, Chayen B, Peltz R, Feldman B, Lipitz S. 2009. Outcome of severely anaemic fetuses treated by intrauterine transfusions. Arch Dis Child Fetal Neonatal Ed 94: F201-F204.

* Williams TN, Weatherall DJ. 2012. World distribution, population genetics, and health burden of the hemoglobinopathies. Cold Spring Harbor Perspect Med 2: a11692.

Yang Y, Li DZ. 2009. A survey of pregnancies with Hb Bart's disease in Mainland China. Hemoglobin 33: 132-136.

Yi JS, Moertel CL, Baker KS. 2009. Homozygous $\alpha$-thalassemia treated with intrauterine transfusions and unrelated donor hematopoietic cell transplantation. J Pediatr 154: $766-768$.

Yuan J, Bunyaratvej A, Fucharoen S, Fung C, Shinar E, Schrier SL. 1995. The instability of the membrane skeleton in thalassemic red blood cells. Blood 86: 3945-3950.

Zhou X, Ha SY, Chan GC, Luk CW, Chan V, Hawkins B, Lam YH, Liang RH, Lau YL. 2001. Successful mismatched sibling cord blood transplant in Hb Bart's disease. Bone Marrow Transplant 28: 105-107.

Zimmerman R, Carpenter RJ Jr, Durig P, Mari G. 2002. Longitudinal measurement of peak systolic velocity in the fetal middle cerebral artery for monitoring pregnancies complicated by red cell alloimmunisation: A prospective multicentre trial with intention-to-treat. $B J O G$ 109: $746-752$. 


\section{$\&_{\mathrm{CSH}}^{\infty} \&$ Cold Spring Harbor

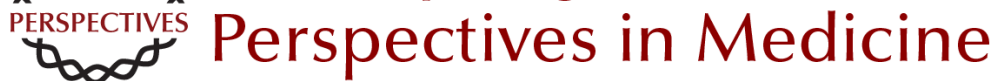

\section{Clinical Manifestations of $\alpha$-Thalassemia}

Elliott P. Vichinsky

Cold Spring Harb Perspect Med 2013; doi: 10.1101/cshperspect.a011742 originally published online March 29, 2013

\section{Subject Collection Hemoglobin and Its Diseases}

The Natural History of Sickle Cell Disease Graham R. Serjeant

\section{Current Management of Sickle Cell Anemia} Patrick T. McGann, Alecia C. Nero and Russell E. Ware

Cell-Free Hemoglobin and Its Scavenger Proteins: New Disease Models Leading the Way to Targeted Therapies Dominik J. Schaer and Paul W. Buehler

Clinical Manifestations of $\alpha$-Thalassemia Elliott P. Vichinsky

Erythroid Heme Biosynthesis and Its Disorders Harry A. Dailey and Peter N. Meissner

Hemoglobin Variants: Biochemical Properties and Clinical Correlates Christopher S. Thom, Claire F. Dickson, David A. Gell, et al.

The Prevention of Thalassemia Antonio Cao and Yuet Wai Kan

The Switch from Fetal to Adult Hemoglobin Vijay G. Sankaran and Stuart H. Orkin
Transcriptional Mechanisms Underlying Hemoglobin Synthesis

Koichi R. Katsumura, Andrew W. DeVilbiss, Nathaniel J. Pope, et al.

Iron Deficiency Anemia: A Common and Curable Disease Jeffery L. Miller

Management of the Thalassemias Nancy F. Olivieri and Gary M. Brittenham

The Molecular Basis of $\beta$-Thalassemia Swee Lay Thein

Erythropoiesis: Development and Differentiation Elaine Dzierzak and Sjaak Philipsen

Erythropoietin

H. Franklin Bunn

Classification of the Disorders of Hemoglobin Bernard G. Forget and H. Franklin Bunn

The Molecular Basis of $\alpha$-Thalassemia Douglas R. Higgs

For additional articles in this collection, see http://perspectivesinmedicine.cshlp.org/cgi/collection/ 